Abstracta Iranica

Revue bibliographique pour le domaine irano-aryen

Volume 40-41 | 2019

Comptes rendus des publications de 2017-2018

\title{
Yazdan Safaee. "A Local Revolt in Babylonia during the Reign of Darius III"
}

\section{Salman Aliyari Babolghani}

\section{(2) OpenEdition \\ 1 Journals}

\author{
Electronic version \\ URL: http://journals.openedition.org/abstractairanica/48261 \\ DOI: 10.4000/abstractairanica.48261 \\ ISBN: 1961-960X \\ ISSN: 1961-960X \\ Publisher: \\ CNRS (UMR 7528 Mondes iraniens et indiens), Éditions de l'IFRI
}

\section{Electronic reference}

Salman Aliyari Babolghani, "Yazdan Safaee. "A Local Revolt in Babylonia during the Reign of Darius III"', Abstracta Iranica [Online], Volume 40-41 | 2019, document 21, Online since 15 July 2019, connection on 20 April 2021. URL: http://journals.openedition.org/abstractairanica/48261 ; DOI: https://doi.org/10.4000/abstractairanica.48261

This text was automatically generated on 20 April 2021.

Tous droits réservés 


\title{
Yazdan Safaee. "A Local Revolt in Babylonia during the Reign of Darius III"
}

\author{
Salman Aliyari Babolghani
}

\section{REFERENCES}

Yazdan Safaee. “A Local Revolt in Babylonia during the Reign of Darius III” Dabir vol. 1, no. $4,2017,51-56$

1 This article discusses the possibility of a local revolt in Babylonia at the beginning of the reign of Darius III before Alexander's expedition on the evidence of the Late Babylonian Uruk Kinglist where, before the name of Darius III, A. Kuhrt has read '[... whose] other name is Nidin-B[el?]'.

2 One interpretation denies the existence of such an usurper and considers this name just as a scribal error. However, Y. Safaee considers him as a local rebel who is not mentioned in the other sources maybe due to the instability and short duration of the revolt. He compares the unstable political situation of Darius III's accession to that of Darius the Great who was a member of a collateral branch who came to throne through political (and military) means just like Darius III. Therefore, the author considers the behavior of this rebel '[whose] other name is Nidin-B[el?]' comparable to that of the usurpers who sought legitimacy against Darius I, as the Bisotun inscriptions recount, by choosing names with a historical background, i.e. names of previous kings. 


\section{AUTHORS}

SALMAN ALIYARI BABOLGHANI

Iran 